\title{
El Museo de Cádiz ante los nuevos retos en redes sociales
}

\author{
José A. Chilía Gómez | responsable de las redes sociales del Museo de Cádiz
}

URL de la contribución <www.iaph.es/revistaph/index.php/revistaph/article/view/4807>

En los últimos meses hemos tenido en el Museo de Cádiz a los equipos de grabación de Cuarto Milenio (Mediaset), Arqueomanía (RTVE) y Zona Historia (Onda Cádiz TV); además, hemos sido portada y protagonistas de numerosos artículos en la prensa local y nuestro director ha sido entrevistado por varias emisoras de radio. No está nada mal para una institución que, antes del 2014, para salir en prensa, poco menos que tenía que hallarse un nuevo sarcófago fenicio en la ciudad. Evidentemente, se trata de todo un logro motivado por la manera de entender lo que es un museo en el s.XXI por parte de todo el equipo del Museo de Cádiz. Pero, claro, yo me encargo de la comunicación y las RRSS, así que voy a "arrimar el ascua a mi sardina".

Allá a finales del hoy más lejano si cabe 2014, pocos museos andaluces éramos capaces de ver el potencial de la presencia de nuestras instituciones en las redes como medio de relacionarse de un modo cercano y accesible con la ciudadanía. La mayoría de los museos, y no solo en Andalucía, tenía perfiles testimoniales donde de manera intermitente y muy académica para nuestro gusto, como mucho presentaban los grandes hitos de sus colecciones y las actividades que tenían lugar en sus instalaciones. Sí había otros que eran auténticos pioneros en la idea de crear comunidad (me gustaría destacar en Andalucía al Museo de Almería y, en España, a los museos "pequeños" de Madrid, como el Cerralbo o el del Romanticismo), que nos abrieron los ojos para ver que en redes el tamaño no importa si las cosas se hacen bien, y poder así alcanzar una notoriedad que antes era impensable.

En nuestro afán por encontrar ese elemento diferenciador que nos hiciera destacar en un mundo tan competitivo y a veces de éxitos tan efímeros, como es el de las redes sociales de instituciones culturales, entendimos

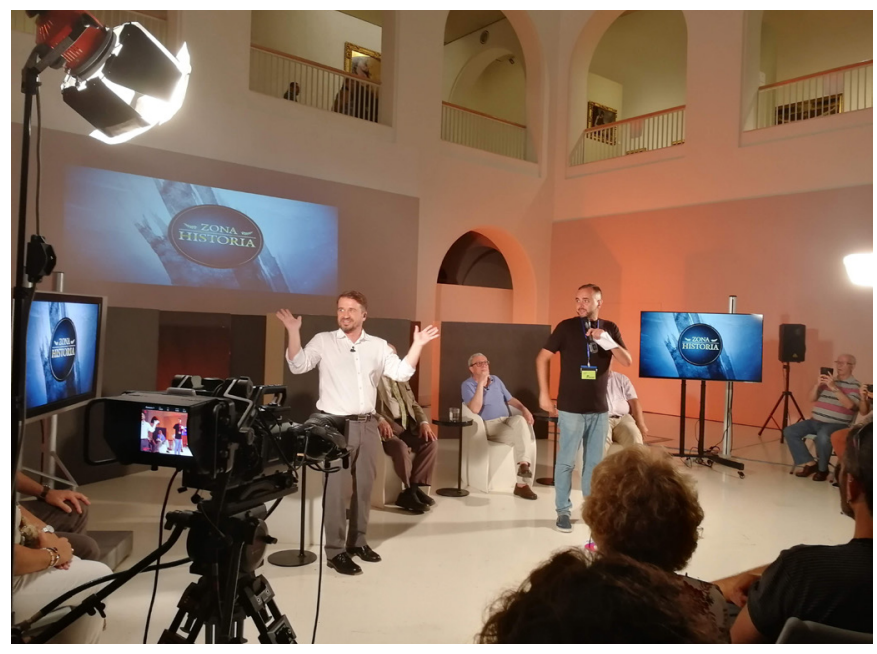

Especial Zona Historia de Onda Cádiz TV sobre el sarcófago femenino en el patio del Museo fue su primer programa fuera de plató | foto José A. Chilía Gómez, autor de todas las imágenes que ilustran la contribución

que una comunicación directa, de tú a tú, salpimentada con el uso de gif, bromas y desdramatizando totalmente el discurso, sin caer en lo chabacano y siempre con la rigurosidad en el horizonte, podría ser lo suficientemente atractivo para nuestra audiencia y generar un engagement que nos convirtiera en un referente. También he de decir que fue un poco por necesidades del guión, ya que el que escribe carece de formación en arqueología y bellas artes. Pero eso, lejos de ser un handicap, acompañado de una curiosidad insana, pronto se convirtió en una virtud, ya que mi manera de ver el museo se asemeja mucho más a la visión del visitante/seguidor medio que al verdaderamente experto en la materia. El hecho es que la cosa funcionaba, cada vez teníamos más seguidores, más likes y un público más activo. Y no solo en España. Además, en las redes, gente tan importante en el Twitter cultural en nuestro país, como pueden ser @ElBarroquista o @LuisPas, por citar solo dos ejemplos, empiezan a destacar nuestra labor. En poco más de 2 años pasamos de tener un Facebook parado 
a debate Comunicación y redes sociales en instituciones culturales

| coordina Candela González Sánchez

a tener casi un total de 25.000 seguidores en nuestros perfiles activos en Facebook, Twitter e Instagram. Todo ello respaldado por éxitos como el ser considerados la tercera institución cultural más influyente de España en Twitter, durante la Museum Week 2019, o el aparecer en numerosos medios europeos con la primera ruta instagrameable de un museo.

Durante el 2019 empezamos a notar que nuestra manera de comunicar en redes y nuestra imagen fresca no se veía reflejada luego en nuestras salas y decidimos intentar solucionar esta carencia con actividades que reforzaran la idea de museo accesible y para tod@s que siempre hemos tenido. No fue fácil. La mayoría de las veces las trabas venían desde algunos compañe-

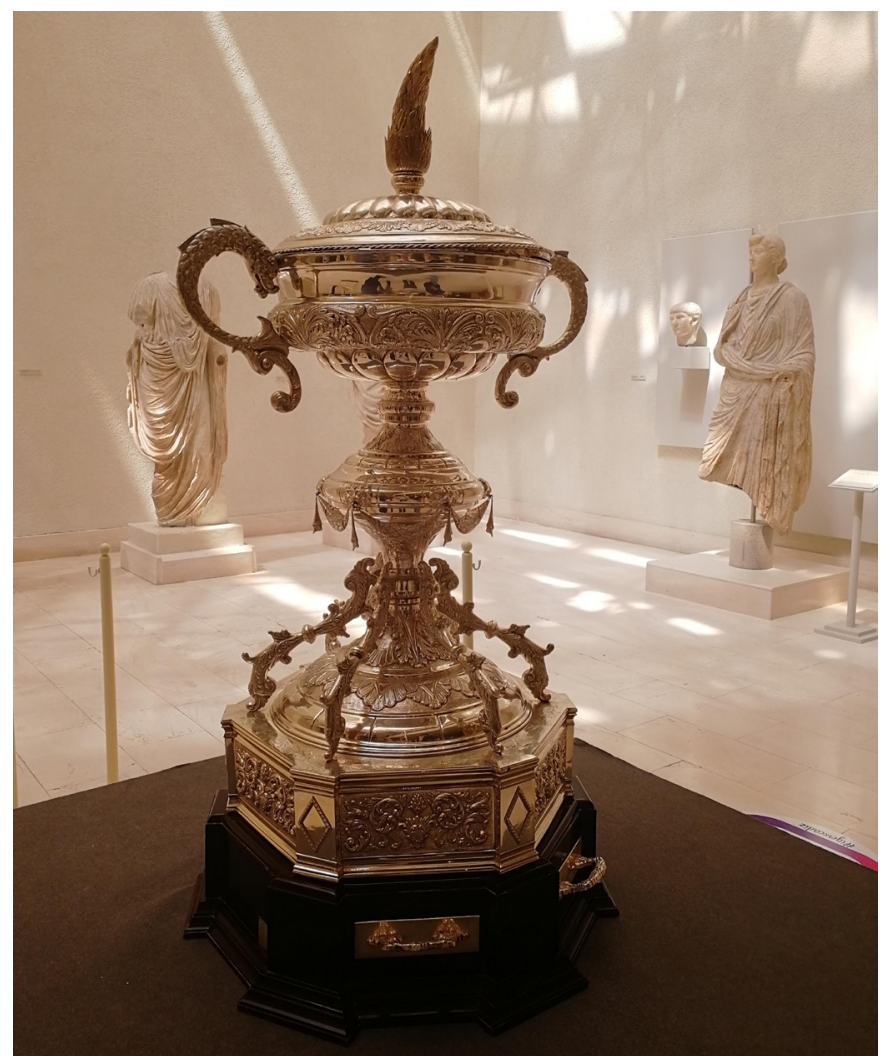

Trofeo Carranza en el patio de estatuaria romana. De la actividad "Un Trofeo de Museo" ros de la misma institución que no entendían ese afán aperturista, pero aún así trajimos el Trofeo Carranza a la Sala de Estatuaria Romana o a Pedro Huertas de @ romaenundiablog para que ejerciera de "arqueólogo de guardia" en nuestro Netflix de las visitas guiadas, entre otras "locas" propuestas.

Y en ello estábamos cuando llegó el tsunami de la COVID-19 y su confinamiento. De pronto ya no habría visitantes, el museo cerraba y sólo nos quedaba una puerta al mundo, las RRSS. Desde un primer momento supimos reaccionar y creamos una serie de propuestas sostenibles desde casa que llamamos El Balcón del Museo creando una analogía con la vida en los balcones que tenía tanto protagonismo en aquellos días de marzo.

Pero este mundo virtual de las RRSS es frenético y lo que ayer valía hoy ya no tiene el mismo valor o pronto queda obsoleto. La pandemia ha acelerado el cambio que se veía venir ya desde 2018, las propias redes y los seguidores demandan cada vez más y más contenidos de calidad y nosotros con los medios que tenemos no se las podemos dar. Por ejemplo, el vídeo y el streaming son dos contenidos imprescindibles en este mundo pandémico donde todo lo que antes proponíamos de un modo presencial tiene que ser obligatoriamente virtual. Es el momento de que las administraciones que se encontraron allá por 2014 con el "chollo" de tener una promoción cultural de bajísimo coste, en ocasiones coste cero, den un paso adelante y apuesten por una difusión en redes de calidad. Para ello considero imprescindible, en primer lugar, el reconocimiento a nivel laboral del trabajo realizado. La mayoría de los y las que nos dedicamos a esto somos personal que tiene otras muchas funciones y además las gestión de las redes, que en la mayoría de las ocasiones no tienen horario (¿a quién no le han preguntado un domingo el horario de apertura?). Es imprescindible que aquello de lo que ya hablamos como una necesidad hace años en las maravillosas jornadas sobre redes en el IAPH, el que exista en las RPTs (Relación de Puestos de Trabajo) de los museos la figura del CM o más bien del social manager, se haga una realidad con 
un sueldo acorde a sus responsabilidades. Es de justicia. Ahora más si cabe. Así como la necesidad de dotar a estos profesionales del material, tanto físico como de software o de preparación necesario, para que los museos andaluces no nos quedemos atrás y perdamos todo lo conseguido en estos años de duro trabajo. Un buen móvil con una tarifa de datos ilimitada para el streaming de actos. El que tengo asignado tiene ya tres años, entonces era gama media y mi tarifa de datos ha sido de $1 \mathrm{~Gb}$ de media, un buen estabilizador para grabar vídeo, un micrófono, un portátil medianamente potente (sí, los PCs destinados a ofimática que tenemos en las oficinas no valen para editar vídeo, cualquier informático lo sabe), el pago de algunas licencias de software de edición (por ejemplo CANVA) y cursos de formación en medios audiovisuales no supondrían un gasto desor-

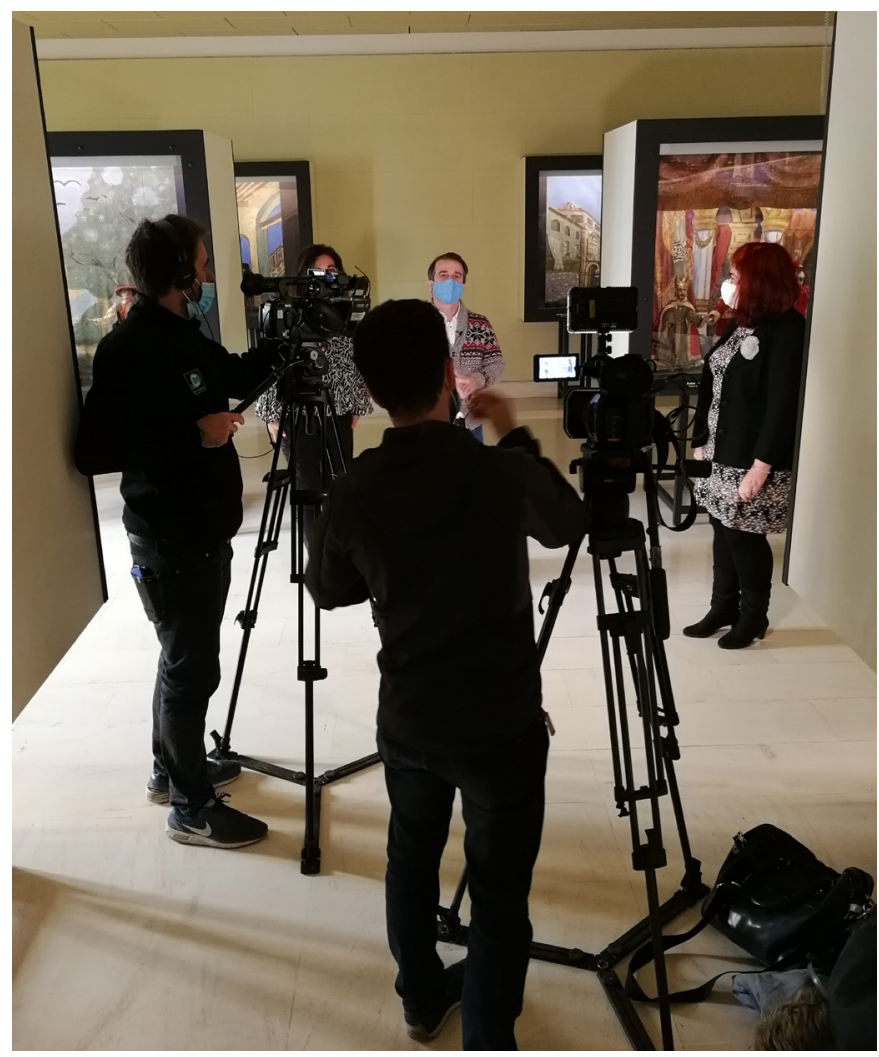

Grabación en el museo del Especial Reyes Magos de Onda Cádiz TV en la sala Tía Norica bitado en proporción a los beneficios que ofrece a nivel mediático nuestro trabajo.

Lo dicho, en un mundo tan frenético, con nuevas interesantes propuestas, como pueden ser TikTok o Twitch, y con cambios constantes en las RRSS donde ya tenemos perfiles, es el momento de dar un paso adelante o quedarnos anclados en algo que fue bonito mientras duró. 